\title{
An Essay of Dramatic Poesy: Main Frame of Dryden's Literary Criticism
}

\author{
Victoria Bilge YILMAZ
}

\begin{abstract}
John Dryden, a great poet of the $17^{\text {th }}$ century English literature, has left a tremendous stamp in literary criticism with his An Essay of Dramatic Poesy (1668), an essay that includes a frame of his literary output. Providing such important aspects for literary criticism like ideas about plays and poetry, Dryden works on the elaboration of Englishness in literature. He claims that it is high time contemporary English authors and critics elevated their literature above that of the ancients and the French. By stressing on the importance of rhyme in poesy, Dryden argues that English plays are better than those in France because they have richer plot and livelier characters. This study will focus on Dryden's Essay and the frame of literary criticism that this Essay puts forward. It will also analyse Dryden's Annus Mirabilis (1667), All for Love (1677), "Mac Flecknoe" (1678-79), and Absolom and Achitophel (1681) in terms of these works' reflection of the Essay's main outline. The study will conclude that what Dryden comes with in his Essay is the precise and clear picture of his talent as a poet and literary critic.
\end{abstract}

Keywords: John Dryden, an Essay of Dramatic Poesy, Annus Mirabilis, All for Love, Absolom and Achitophel

\section{John Dryden'in Dramatik Poesy, Bir Deneme Adlı Eserinde Edebi Eleştiri ve Üslup} Değerlendirmesi

$\ddot{\mathrm{O} z}$

17. yüzyıl İngiliz edebiyatının önemli yazarlarından olan John Dryden'ın edebi yapıtlarının ana çerçevesini Dramatik Poesy, Bir Deneme (1668) adlı eseri oluşturmaktadır. Bu eser edebi eleştiride büyük bir iz bırakmıştır. Oyun ve şiir ile ilgili önemli fikirlerini bu eserinde ortaya koyan Dryden, İngilizlerin edebiyata katkılarını ve önemini vurgulamaktadır. Dryden, İngiliz edebiyatının, eski çağlar ve devamındaki Fransız edebiyatlarından daha üstün görülmesi için vaktin geldiğini savunmaktadır. Dryden, edebiyatta şiirdeki kafiyenin önemine dikkat çekerken, İngiliz tiyatro oyunlarının Fransız tiyatro oyunlarından daha iyi olduğunu da iddia etmektedir. İngiliz oyunlarının konu-olay örgüsünün daha zengin ve karakterlerin daha canlı olduklarını vurgulamaktadır. Bu çalışma, Dryden'in Deneme'si ve bu Deneme'nin öne sürdüğü edebi eleştiriyi ele almaktadır. Ayrıca bu çalışmada Dryden'ın Annus Mirabilis (1667), Her Şey Aş̧ Uğruna (1677), "Mac Flecknoe" (1678-79) ve Absolom ve Akitofel (1681) adlı eserleri de edebi eleştiri çerçevesinde incelenecektir. Dryden'ın Deneme'de öne sürdüğü fikirlerin aslında şairin şïr ve edebi eleştiri bakımından kendi yeteneklerinin yansiması olduğu, örneklerle ortaya konulacaktır.

Anabtar Kelimeler: John Dryden, Dramatik Poesy, Bir Deneme, Annus Mirabilis, Her Şey Aşk Uğruna, Absolom ve Akitofel

\section{Atıf İçin / Please Cite As:}

Yllmaz, V. B. (2022). An essay of dramatic poesy: Main frame of Dryden's literary criticism. Manas Sosyal Araștırmalar Dergisi, 11(1), 1-9.

Geliş Tarihi / Received Date: 22.02.2021

Kabul Tarihi / Accepted Date: 24.09.2021

\footnotetext{
${ }^{1}$ Assoc. Prof. Dr. - Assistant Director, School of Foreign Languages, Ankara Y1ldırım Beyazıt University, vikelay@gmail.com (iD ORCID: 0000-0002-9807-9233
} 


\section{Introduction}

The $17^{\text {th }}$ century and the Restoration Period of English literature witnessed a development of a man of letters, England's first Poet Laureate, John Dryden (1631-1700), an author of many impressive works, among which there are plays, prose, satiric verses, and literary criticism. Although, no doubt, a great bulk of his literary production demands applause and veneration, in the middle of his outstanding creative works there takes its undeniably strong position his literary criticism expressed in his An Essay of Dramatic Poesy (1668). The Essay is, in fact, a conversation between four people: Eugenius, Crites, Lisideius, and Neander. Generally speaking, the Essay tends to elevate English drama over the one from French and ancient oeuvre. This study will trace Dryden's ideas with reference to literary criticism, which bloomed in the Essay, in his Annus Mirabilis (1667), All for Love (1677), "Mac Flecknoe" (1678-79), and Absolom and Achitophel (1681), which appear in this sequence according to the dates of publication. While Annus Mirabilis, "Mac Flecknoe" and Absolom and Achitophel are going to be studied as the examples of rhyme, All for Love is going to be scrutinised as an example for rich characterisation and the exhibition of human passions.

John Dryden, who was a dominant figure in the Restoration Period, produced a wide range of genres from satire to religious writing. Having established his bright career as a poet and a critic, Dryden left his indelible mark on the age in English Literature, the Age of Dryden. His An Essay of Dramatic Poesy serves like a light to illuminate his total literary production. The Essay "is Dryden's first effort at literary theory and one of the most elegant and important contributions to criticism between Sidney's Apology for Poesy (1587) and Pope's Essay on Criticism (1711)." (Zwicker, 1998, p. 188) Obviously, Dryden takes his place among such notable critics like Sidney and Pope. His Essay contributes greatly to his legendary career as a poet and a critic. The Essay can be roughly outlined as Dryden's preference for the moderns rather than the ancients, the vindication of the creative strength of the English authors as opposed to the French ones, the importance of fusion of genres, the preference for the more lively and crowded plays with main plots and subplots, and rhyme. As Zwicker states, the categories in this outline became "central themes of Restoration criticism ... Dryden's rehearsal of these topics is casual and brilliant, and they recur throughout the criticism of the age." (1998, p. 189) Indeed, the ideas Dryden gathered in his Essay reverberated throughout the works of contemporary authors.

\section{An Essay of Dramatic Poesy: Main Frame}

The $17^{\text {th }}$ century was a fragile age in the history of England due to its attempts at huge political movements and vast changes. Parallel to this, English literature witnessed a demand to withstand foreign influence and dominance. Thus, Dryden's role as a poet of this age was to enrich the political stance of the monarch, Charles II, by his panegyrics as well as to bring forth to the surface the idea that English literature is immaculate in all terms. It is possible to bring forth three main arguments in the Essay for the acclaim of English literature: English poesy is well beyond the poesy of the ancients; English poesy or plays are richer than that of the French; and the rhyme in English poesy is immaculate. The Essay, as a result, highly praises the advancement of English poesy, which even surpasses that of the ancients. This is clearly expressed in what Eugenius says:

\section{[T]here is no man more ready to adore those great Greeks and Romans than I am: but on the other side, I cannot think so contemptibly of the age in which I live, or so dishonourably of my own country, as not to judge we equal the ancients in most kinds of poesy, and in some surpass them; neither know I any reason why I may not be as zealous for the reputation of our age, as we find the ancients themselves were in reference to those who lived before them.' (Dryden, 1889, p. 14-15)}

Dryden's attempt in his Essay is not to condemn the ancients or show that they do not deserve the acclaim they have received. On the contrary, he acknowledges their credit in English literature, but, at the same time, equals the English authors to the ancients. In other words, Dryden tries to shatter the binary oppositions between the ancients and the English and as Eugenius states, "nothing seems more easy to him, than to overcome those whom it is our greatest praise to have imitated well, for we do not only build upon their foundations, but by their models." (Dryden, 1889, p. 18) Eugenius pays tribute to the ancients, in fact, by saying that the English poets' greatness lies in their opportunity to follow the ancients. Eugenius, the mouthpiece for Dryden's ideas with reference to the importance of the English authors, goes on and adds that English poets "first taught us to mould our thoughts into easy and significant words, - to retrench the superfluities of expression, - and to make our rime so properly a part of the verse, that it should never mislead the sense, but itself be led and governed by it." (Dryden, 1889, p. 16) 
Eugenius' words, in a way foreshadowing a Romantic step in poetry, stress the importance of easy language in a poem - a language that is precise and clear. In other words, there is always this lightness of transformation of ideas. Significant meaning is conveyed easily and simply because the language is devoid of the heaviness of unnecessary phrases and statements in English poesy. What is meant is said directly without any kind of gratuitous decoration of words and phrases.

Besides the ancient poets, against whose background Dryden locates the English literature, there is also the presence of the French literature in the Essay. As one of the main themes of the Essay is to defend the English contemporary poets, surely, French literature is regarded as the one that should be relegated in comparison with the English. In the inaugural "To the Reader" part of his Essay Dryden states: "The drift of the ensuing discourse was chiefly to vindicate the honour of our English writers, from the censure of those who unjustly prefer the French before them." (Dryden, 1889, p. 7) Apparently, Dryden tries to establish a new school of poetry by proclaiming a new technique of approaching poesy - by developing English poesy and by analysing it against the background of its own authors. Eugenius mentions Sir John Suckling, Mr. Waller, Sir John Denham, and Mr. Cowley whose language he accepts as "even", "sweet", "flowing", "majestic", "correct", "elevated", "copious", and "full of spirit" (Dryden, 1889, p. 16) in comparison with the French. Neander's comments on the difference between the English and French poesy show a great challenge to latter:

Tis true, those beauties of the French poesy are such as will raise perfection higher where it is, but are not sufficient to give it where it is not: they are indeed the beauties of a statue, but not of a man, because not animated with the soul of poesy, which is imitation of humour and passions. (Dryden, 1889, p. 54)

What Neander says here is quite a loud pronouncement because he claims the French lack the soul of poesy. The claim here is that the French poesy belongs to a limited range of scope and cannot thrive all of sudden where it does not exist. In other words, it is not influential; it does not evoke a sense of inspiration in a person. It can also be claimed that while the French just imitate the ancients, the English imitate them and add their own hue to the poesy. That is why Neander likens the French poesy to the beauties of a statue and that of the English to a living man.

One of the reasons why the French lack soul in their literature is their inability or reluctance to blend genres in their plays. As Neander adds, life is not based only on one genre - tragedy or comedy. Life has a soul when it embraces both poles, sometimes at the same time. And when the French have come to understand it, maintains Neander, they started to imitate the English: "But of late years Moliere, the younger Corneille, Quinault, and some others, have been imitating afar off the quick turns and graces of the English stage. They have mixed their serious plays with mirth, like our tragi-comedies, since the death of Cardinal Richlieu." (Dryden, 1889, p. 55) Neander concludes that the English literature has reached the stage from where it influences French literature. Yet, as Neander states, even though there is a glimpse of comedy in French tragedies, it is so "thin-sown" (Dryden, 1889, p. 55) that it cannot manifest its profound possibilities as a genre. Indeed, French plays withstand changes and development to their own dismay.

Another reason for French literature's lack of soul is its rigidity in terms of plot and content. Unlike the French plays, the English plays are crowded in terms of content; there are many characters and many plots. And related to this, Neander argues: "Tis evident that the more the persons are, the greater will be the variety of the plot ... you will find it infinitely pleasing to be led in a labyrinth of design." (Dryden, 1889, p. 59-60) Neander links the high number of characters with the richness of plot and ultimately to the audience's pleasure of discovery. It is due to the complexity of the plot that the audience becomes amazed by the play. In addition, as Neander states, the English like action in their plays: "I know not; but they will scarcely suffer combats and other objects of horrour to be taken from them." (Dryden, 1889, p. 61) Feelings of rivalry, fear, and victory are the elements of plays through which the audience feels the soul of the work.

Another category in poesy that the four speakers in the Essay dwell upon is the idea of the rhyme in poesy. It is here that the four speakers do not agree with each other. Neander, commonly accepted as the mouthpiece of Dryden himself, states that rhyme enriches a piece of work:

I deny not but blank verse may be also used, and content my self onely to assert, that in serious plays where the subject and characters are great, and the plot unmixed with mirth, which might allay or divert these 
concernments which are produced, rhyme is there as natural, and more effectual then blank verse. (Dryden, 1889, p. 84)

Contrary to Crites, who defends the priority of the blank verse over rhyme, Neander finds rhyme as natural as an authentic speech. And he gives an example of Fletcher, who wrote in verse. (Dryden, 1889, p. 84) And when Crites argues that rhyme is not natural and that people do not speak in rhyme when they communicate in ordinary life circumstances, Neander answers that in that case neither blank verse nor rhyme is natural: "neither does any man speak in blank verse, or in measure without rhime." (Dryden, 1889, p. 86) Yet, Neander admits rhyme's inappropriateness for the comedies. At the end of the Essay, Neander states the following:

Thus then the second thoughts being usually the best, as receiving the matures digestion from judgement, and the last and most mature product of those thoughts being artful and laboured verse, it may well be inferred, that verse is a great help to a luxuriant fancy, and this is what that argument which you opposed was to evince. (Dryden, 1889, p. 99)

Neander's main idea here is his support for the careful thought process the result of which is the pure outcome in verse. So what the reader has at hand is a piece of literary work with immaculate language and ideas. In short, rhyme is the form through which a poet transforms his/her ideas to the reader and which finds a positive feedback from Dryden.

\section{Dryden's Literary Works through the Frame of His Essay}

Dryden's Essay provides the reader with a main frame through which it is possible to analyse his poems and plays. With a unique linguistic style in his poems, Dryden furthers his manifold ideas to the reader. The beauty of his poems lies not only in his ability to play with language, but also in his extraordinary style of choosing a subject matter to dwell upon. Although he famously supports the monarchy and often praises the deeds of the king, he deftly chooses the minor topics which he sprinkles all around in his poems and plays. In this part of the study, Dryden's Annus Mirabilis, All for Love, "Mac Frecknoe" and Absolom and Achitophel will be analysed against the background of his Essay.

To begin with, let's look at how Dryden works out his idea of the greatness of the English poesy over that of the others. To be more precise, even though he does not establish the binary oppositions between this or that, his stance is more than clear in this regard. In other words, although it would be a difficult task to outline the characteristics of the English poesy that make it better than the poesy of the other nations or periods, it can be easily seen that Dryden approaches the English in the same manner in all terms. In other words, it is possible to see the elevation of the English nation in Dryden's works. Dryden's Annus Mirabilis: The Year of Wonders 1666, an elaboration on the "wonderful year" as the title suggests, has been regarded as his longest poem. The poem ardently praises the English fleet for their double victory over the Dutch while celebrating English people's stamina to survive the Great Fire of London in 1666 and to withstand its drastic consequences. Not surprisingly, a poet, for whom English poesy stands above all other poesies, dramatises the English nation's experience in his poem. What is more, Annus Mirabilis celebrates the coronation of the king, Charles II, as well as his supremacy as a monarch and a leader in a war:

He without fear a dangerous war pursues,

Which without rashness he began before:

As honour made him first the danger choose,

So still he makes it good on virtue's score. (Dryden, Annus Mirabilis, stanza 45)

It is not a wonder that Dryden's idea about the English's superiority over the French in terms of poesy can be further applied to politics. That is why celebrating the monarch of the English nation and his deeds becomes the central theme in Dryden's poem. Yet, Dryden's motive for this central theme has been looked for in some other place, as Corns states: "For Dryden, the laureateship implied grander responsibilities ... nothing short of the public celebration and defence both of the king and of James, Duke of York, the heir apparent and himself a significant patron of the poet." (2007, p. 361) Corns' and other critics' ideas in this regard may be valid; however, what cannot be refuted is the fact that Annus Mirabilis is a wonderful and a successful poem about a wonderful year.

Dryden's another successful poem is Absolom and Achitophel, a satire, in which he beautifully depicts such important political events in the country like the Exclusion Crisis, the Popish Plot, and the 
Monmouth Rebellion. Exploiting a Biblical tale for the purpose of satirising an English monarch and his politics can be seen as a sign of generalising English nation's circumstances all through ages and territory. Drawing an analogy between Charles II's illetigimate son, the Duke of Monmouth, and the Biblical hero Absolom brings to mind Dryden's tendency to put English nation over other nations. Indeed, the poem, in a way, foreshadows the consequences of the Monmouth Rebellion. Was the poem a warning to protect the monarch, Charles II, or the succeeding James, Charles' Catholic brother? Was it a political treatise on how to manage crises or was it a way of protecting Monmouth? These questions can be answered by various critics differently; yet, what is left to the reader is a beautiful poem in which the accounts of one of the most significant turns in English history are portrayed. Indeed, one of the aims of Dryden in writing this poem might be his wish to make the succeeding generations remember the events of the Age of Dryden, the age through which Dryden looked at the world and through which England was seen to him. In other words, Dryden's idea about the greatness of English poesy that he focuses on in his Essay is magnificently put into practice in his Absolom and Achitophel. Any person profoundly interested in literature would easily bring to mind English nation during the reign of Charles II when faced with Dryden's Absolom and Achitophel, although the poem bears the Biblical names. Cannot we think that it was precisely this motive in Dryden's mind during his creation of this poem?

Dryden's loud exclamation about the superiority of the English prose over that of French in his Essay can find its reflection in his play All for Love, a tragedy in five acts that focuses on the last hours of Antony and Cleopatra's love affair in Alexandria. Being a successful Roman general, Antony falls in love with an irresistible Egyptian queen, Cleopatra, but their relationship is doomed to failure. Actually, the play pays tribute to Shakespeare's Antony and Cleopatra (1603-1607), although it seems that Dryden's version was as popular as Shakespeare's. All for Love is Dryden's work on tragedy whereas in his Essay, he mentions about blending of genres. His story of Antony and Cleopatra's tragic love barely includes comic effects. What is more, the play is written in blank verse whereas rhyming was highly preferred in the Essay. Nevertheless, All for Love successfully accomplishes Dryden's aim to have a complex plot. Despite the fact that the play is only about the last hours of Antony and Cleopatra, it is full of unexpected encounters, twists of fate, and desperate conditions. The play's success lies not only in its Shakespearean repetitious love story, but in its wealth of content. There is deep belief in love, base animal desire towards the opposite sex, strength and desire to overcome barriers that prevent love between Antony and Cleopatra, profound belief in the power of loyalty on the side of Octavia, division of an individual into responsibility and love-driven personality, and conspiracies on the side of Alexas.

In All for Love characters' passions and colourful personalities grant a wealthy outlook to the play and create a range of various angles. The Gentleman talks about Antony in the following manner:

He eats not, drinks not, sleeps not, has no use

Of anything, but thought; or if he talks,

'Tis to himself, and then 'tis perfect raving:

Then he defies the world, and bids it pass,

Sometimes he gnaws his lips, and curses loud

The boy Octavius; then he draws his mouth

Into a scornful smile, and cries, "Take all,

The world's not worth my care." (Dryden, All for Love, Act I, Scene I)

Here, the images of Antony present a vivid picture of the passion, which plays a major role in Dryden's aesthetics. The richness of the play makes itself evident when the reader/audience enters the world of passions and emotions on an individual and personal ground. Antony's vaccilation between the two poles of his individuality is clearly portrayed and this vaccilation makes him a colourful character. His inability to stick to one pole makes his characterisation rich and vivid. When he sees Cleopatra, he forgets about his responsibilities and his determination to give her up: "My eyes, my soul, my all!" (Dryden, All for Love, Act II, Scene I) Similarly, when he sees his wife Octavia and his children, he embraces them and asks them to take him away: "I am vanquished: take me, / Octavia; take me, children, share me all." (Dryden, All for Love, Act III, Scene I) So, the audience sees Antony's various colours which change as the circumstances change. It is not hypocrisy; it is human nature; it is Antony's war with himself. It is not attributable only to Antony; everybody can associate himself with this character. And at the end, when Antony learns about Cleopatra's "unreal" suicide, he exclaims: "Now she's dead, / Let Caesar take the world." (Dryden, All for Love, Act V, Scene I) Consequently, Antony kills himself and ten-year old love 
leaves its stamp in the audience's minds throughout ages. Similar to Antony, Cleopatra's expression of her feelings shows that she is lost somewhere between her passion and her responsibility for her country:

I am no queen:

Is this to be a queen, to be besieged

By yon insulting Roman, and to wait

Each hour the victor's chain? These ills are small:

For Antony is lost, and I can mourn

For nothing else but him. Now come, Octavius,

I have no more to lose! prepare thy bands;

I'm fit to be a captive: Antony

Has taught my mind the fortune of a slave. (Dryden, All for Love, Act II, Scene I)

These lines expressed by Cleopatra show that a queen has become a slave because of her feelings. Her words can be used to describe a country's condition under an enemy's attack and surroundings. Yet, the enemy is within herself. While the reader reads the play or the audience watches it on stage, he/she is bewitchingly entrapped in a web of themes, characters, and plot. In other words, the play is not limited to a love affair between two strong political figures; the love story is encircled in a wide range of political, social, and family occurrences that, in fact, shape that love story. Dryden's aim was not to re-work the famous political figures like Antony or Cleopatra, but to exploit these popular names to depict the multilateral structures - social, political, psychological, national, or familial - that may, or actually, do encircle and influence a human being, even as strong as Antony. This is a good example of what Dryden meant when he was supporting English plays against the French ones. He states in his Essay that English plays are about human passions whereas French plays are cold.

When it comes to rhyme, Dryden seems to spill over his talent into his poems. What he accomplishes as his own ideal mentioned in his Essay is his perfect rhyme. The outcome is beautiful in his Annus Mirabilis. Although the poem is long, rhyme does not lack its strengths and the lines flow one after the other in an ordered rhyme:

The dastard crow that to the wood made wing,

And sees the groves no shelter can afford,

With her loud caws her craven kind does bring,

Who, safe in numbers, cuff the noble bird. (Dryden, Annus Mirabilis, stanza 87)

The words "wing" - "bring" and "afford" - "bird" create a rhyme and at the same time convey a clear flow of meaning from one line to the other just as Neander states about rhyming in the Essay; rhyming does not prevent the naturalness of the context. Even such serious and at the same time concrete event like war is described in a rhymed poem in Dryden's work:

Yet like an English general will I die,

And all the ocean make my spacious grave:

Women and cowards on the land may lie;

The sea's a tomb that's proper for the brave. (Dryden, Annus Mirabilis, stanza 101)

The description of the harshness of a war in a verse form does not eradicate the closeness of the description to reality. Rhyming is a kind of control of language. Language is not given freedom as it is in prose. And when Dryden speaks about the importance of rhyme in his Essay, he declares his desire to have control over his language. Dryden endorsed rhyme in verse just before the dawn of the novel form, prose writing. Thus, as Frank states, "Dryden's critical career has traditionally been viewed as the site of struggle between his adherence to a neo-classicism, which offers unhampered access to the achievements of the literary past, and a modernism, which insists on the ability of present writers to 'improve' that past." (2004, p. 15) In other words, praising the king in Annus Mirabilis through heroic style and using rhyme is the sign of Dryden's adherence to neo-classicism because he uses previously developed techniques in poesy. Does this idea refute Dryden's another idea about the superiority of the contemporary $17^{\text {th }}$ century poets over the ancients or over the French? In this regard, Zwicker says that "the Essay reminds us that the relations between native and foreign sensibilities, even sensualities, were very much in negotiation in the 1660s, that French neoclassicism did not sweep native genius aside, and that earlier English drama would prove crucial to the unfolding of English aesthetics." (1998, p. 190) In other words, Dryden does 
not give up French neoclassicism, but develops it into a more extravagant and triumphal aesthetics with an English twist.

Rhyme is used by Dryden in his satire too. And as Alexander states, "Dryden found that the English closed couplet was too neat for tragedy, and made it instead the vehicle for satire." (2000, p. 162) Closed couplet demands a more controlled language as its two lines should complete a grammatical structure and convey a meaningful idea. "Mac Flecknoe" and Absolom and Achitophel are his two significant satiric verses in which Dryden plays with rhyme to the full content. "Mac Flecknoe" satirises Thomas Shadwell (16401692), a playwright whom Dryden regards as being dull. The poem is in a mock-heroic style; it speaks of Nonsense of a poet as if it is a grandiose realm:

All human things are subject to decay,

And when fate summons, monarchs must obey.

This Flecknoe found, who, like Augustus, young

Was called to empire, and had governed long;

In prose and verse, was owned, without dispute,

Through all the realms of Nonsense, absolute. (Dryden, "Mac Flecknoe", lines 1-6)

Obviously, Dryden's work on rhyming in his poems imposes a great control over language, grammatical structure, and meaning at the same time. Dryden's rhyme becomes more extravagant in his Absolom and Achitophel, a masterpiece in satire of the age. The subject matter is as great as the monarch of the country; it is about a king and his illegitimate son, who wants to usurp the throne. The poem is about a Biblical King David and his illegitimate son Absolom. Nevertheless, what Dryden refers to in this poem is the problematical situation between Charles II and his illegitimate son the Duke of Monmouth. Because the context is grand, the style is also heroic:

In pious times, ere priestcraft did begin,

Before polygamy was made a sin;

When man on many multiplied his kind,

Ere one to one was cursedly confined;

When nature prompted and no law denied

Promiscuous use of concubine and bride;

Then Israel's monarch after Heaven's own heart,

His vigorous warmth did variously impart

To wives and slaves; and, wide as his command,

Scattered his Maker's image through the land. (Dryden, Absolom and Achitophel, lines 1-10)

Absolom and Achitophel has become an epitome of Dryden's ideas about rhyming in poems as the poem creates a perfect parallelism between the Biblical characters and the implied English monarch in a precisely structured and controlled linguistic form.

Bearing in mind Dryden's Essay and his works, it is not wrong to state that his approach is neither totally neo-classical, nor totally English. As it is clearly shown in the Essay, he has a neo-classical grasp, as it is observed in his desire for rhyme in his Annus Mirabilis, "Mac Flecknoe" and Absolom and Acbitophel, and a modern attitude, as it is evident in his play, All for Love. In this play, there is passion and there are human beings' inner worlds revealed to the audience. Criticisms about Dryden as a poet are usually surrounded by his close attachment to the monarchy, which is often said to be the main reason for his great success as a poet. Yet, as this study brings forth, Dryden's success as a poet and a playwright lies mainly in his poetic and artistic talent. This ability to draw vivid and clear pictures in his poems through the accurate use of language obviously puts Dryden above many of his contemporaries. To sum up, his use of rhyme and the wealth of plot and passions in his plays gain momentum not because they are largely outlined in his Essay, but because they are inherent in his poetic mind. It is with this mind that Dryden comes out as a poet and a critic and writes his Essay to establish a frame for his works.

\section{Ethical Declaration}

In the writing process of the study titled "An Essay of Dramatic Poesy: Main Frame of Dryden's Literary Criticism", there were followed the scientific, ethical and the citation rules; was not made any falsification on the collected data and this study was not sent to any other academic media for evaluation. Since the document review was conducted in this study, there is no need for an ethics committee decision. 


\section{References}

Alexander, M. (2000). A bistory of English literature. London: Macmillan Foundations.

Corns, T. N. (2007). A history of seventeenth-century English literature. Oxford: Blackwell Publishing.

Dryden, J. (1993). Absolom and Achitophel. Norton anthology of English literature. Vol. I, Sixth Ed. New York: WW Norton and Company.

Dryden, J. All for Love. Retreived from http://www.gutenberg.org/cache/epub/2062/pg2062.html on 28 December 2020.

Dryden, J. Annus Mirabilis Retreived from http://www.online-literature.com/dryden/poetical-works-vol1/8/ on 28 December 2020.

Dryden, J. (1889). An Essay of Dramatic Poesy. Oxford: Clarendon Press. Retrieved from https://archive.org/stream/essayofdramaticp00dryduoft?ref=ol\#page/16/mode/2up 3 February 2021.

Dryden, J. (1993). Mac Flecknoe. Norton Anthology of English Literature. Vol. I, Sixth Ed. New York: WW Norton and Company.

Frank, M. (2004). Gender, theatre and the origins of criticism: From Dryden to Manley. Cambridge University Press.

Zwicker, S. N. (1998). John Dryden. The Cambridge Companion to English Literature 1650-1740, (pp. 185-203). Cambridge University Press.

\section{TÜRKÇE GENİ̧̧ ÖZET}

İngiliz edebiyatının 17. yüzyılı için önemli bir figür olan John Dryden (1631-1700), İngiltere'nin ilk atanmış Saray Şairidir. Dryden'ın eserleri arasında oyunlar, düz yazı, hiciv şiirler ve edebi eleştiri yazıları mevcuttur. Tüm eserleri çok önemli olsa da, Dramatik Poesy, Bir Deneme (1668) adlı edebi eleştiri yazısı tüm eserlerin tacıdır. Dryden'ın Deneme'sinde Eugenius, Crites, Lisideius ve Neander adındaki dört kişinin konuşması yer almaktadır. Genel olarak Deneme, İngiliz edebiyatını başka halkların ve dönemlerin edebiyatlarından üstün kılmaktadır. Bu çalışma Dryden'ın Deneme'de dile getirdiği edebi eleştiri çerçevesini Annus Mirabilis (1667), Her Şey Assk Uğruna (1677), "Mac Flecknoe" (1678-79) ve Absolom ve Akitofel (1681)adlı çalışmaları da dikkate alınarak irdelemektedir. Bu eserler, kafiye açısından incelenirken, Her Şey Aş̧ Uğruna adlı oyunu da zengin olay örgüsü ve karakterlerin yoğun duyguları açısından irdelenecektir. 17. yüzyıl İngiltere'si büyük siyasi çalkantılarla başa çıkarken, ülkenin yazarları ve şairleri eserlerinde İngilizlerin üstünlüğ̈̈nü vurguluyorlardı. İngiliz sarayına sadık olan John Dryden, Deneme’sinde İngiliz edebi eserlerinin üstünlüğ̈nün üzerinde dururken çağın gerektirdiği görevini yapmış oluyordu. Dryden ilk olarak Deneme'sinde İngilizlerin edebi eserlerinin eski çağdaki edebi eserlerden daha iyi olduğunu savunmaktadır. Daha iyi olduklarının sebebini ise İngilizlerin eski çağlardaki yazarları taklit ederek kendilerinden de bir şeyler katmalarını ve şiirlerini zenginleştirmelerini göstermiştir. Ayııca, İngiliz ve Fransız edebiyatlarını karşılaştırarak, İngiliz oyunlarının daha canlı olduğunu vurgulamıştır. Fransız eserlerini ise yetersiz ve soğuk olarak görmektedir. İngiliz oyunlarında hem komedi hem trajedi gibi unsurların bulunmasını överken, Fransız oyunlarında tek unsura odaklanılmasını eleştirmektedir. Ayrıca, Dryden’a göre Fransız eserlerindeki olay örgüsü zayıf ve düzdür. Son olarak Dryden, Deneme'sinde kafiyenin öneminin altını çizerken, kafiye kullanımının dili sıkıca kontrol altında tutmak olduğunu anlatmaktadır. Kafiye kullanımının sıkı bir düşünce sürecinden geçtiktikten sonra ortaya çıktığını savunan Dryden, yazılan her şeyin uzun bir süreçten sonra sunulması gerektiğini belirtmektedir. Kendi eserlerine gelince, Annus Mirabilis adlı uzun şiiri İngiltere için önemli bir dönemi okuyucuya aktarmaktadır. Bu eserde İngiliz kralın önemli zaferlerini anlatan Dryden, İngilizlerin önemini bir daha vurgulamaktadır. Şiirde İngilizlerin birkaç savaş1 kazandıklarını ve hepsinin arkasında kralın olduğunu belirtmiş ve İngiliz halkının üstünlügünü hatırlatmıştır. Ayrıca İngiliz halkının büyük Londra yangınında da kahramanca hareket ettiğini de bu şiirde anlatmaktadır. Böylece, İngilizlerin sadece edebiyatta değil, pek çok alanda yüce bir halk olduğunu göstermeye çalışmıştır. Absolom ve Akitofel adlı uzun ve çarpıcı hiciv şiirinde ise İncil'deki kral ve gayri meşru oğlunun isyan hareketlerini anlatırken, İngiliz kralı ve onun gayri meşru oğlunun isyana kalkışmasına gönderme yapmaktadır. İngiliz kralı II. Charles’ın veliahdı olmadığından, kardeşi James tahta geçme hazırlıkları içindeydi. Charles'ın gayri meşru oğlu Monmouth Dükü'nün tahtı ele geçirme planlarını bu şiirde ustaca anlatmaktadır. İncil hikâyelerini İngiliz monarşisine uyarlama metoduyla Dryden, İngilizlerin varlığını dini bir vasfa da büründürmeye çalışmıştır. Ayrıca sade bir dille anlatılan hikâyeyi yüzlerce sene sonrasına taşıyarak İngiliz tarihinin bir kısmını da ölümsüzleştirmiştir. Her Şey Aşk Uğruna adlı oyununda Dryden, Shakespeare'ın ünlü Antonius ve Kleopatra adlı oyununa gönderme yaparak, meşhur Romalı komutan Antonius ve Mısır kraliçesi Kleopatra arasındaki aşkın son saatlerini anlatmaktadır. En az Shakespeare'in oyunu kadar sürükleyici ve başarlı olan Her Şey Aşk Uğruna adlı eser, Dryden'ın Deneme'de öne sürdüğ̈ zengin olay örgüsü ve duygu dolu karakterler kurallarına uymaktadır. Oyundaki sahnelerde aşk, ihtiras, ihanet ve görev aşkı arasında sıkışıp kalan Antonius, ülkesi ve aşkı arasında seçim yapmak zorunda kalan Kleopatra ve eşi Antonius'un ülkesine dönmesini sabırla bekleyen Oktavia'nın yaşadığı 
duygu dolu sahneler oldukça ilgi çekicidir. Antonius, bir yandan Kleopatra’yı unutmak isteyip, onu görünce ona sımsıkı sarılmaktadır. Fakat eşini ve çocuklarını görünce ülkesine dönmek istemektedir. Duygudan duyguya giren Kleopatra'nın ölüme doğru giden anları oyunda canlı bir şekilde sergilenmektedir. Her insanın yaşayabildiği duyguları oyununa ustaca aktaran Dryden, bunun gibi sahnelerin Fransız oyunlarında olmadığını iddia etmektedir. Kafiye konusuna gelince, Dryden yeteneğini konuşturmaktadır. Şiirleri her ne kadar monarşi düzenini savunmak için yazıldığı iddia edilse de şiirlerindeki kafiye düzeni çok güçlü ve anlamlıdır. Annus Mirabilis, "Mac Flecknoe" ve Absolom ve Akitofel adlı şïrlerindeki siyasi içerikleri bir yana bırakıp sadece kafiye düzenine bakıldığında okuyucuya şiir okuma zevkini yaşatan eserler olduğu görülebilir. Annus Mirabilis ve Absolom ve Akitofel adlı şiirlerinde Dryden, bir ülkenin önemli olaylarını ve kralın başarılarını anlatırken kafiyeyi ustaca kullanmış ve anlamı kafiye ile beraber vermiştir. Aynı kafiye ustalığ "Mac Flecknoe" adlı şiirinde de görülmektedir. Diğer şiirlerinden farklı olarak bu eser, büyük insanların büyük başarılarını değil, küçük ve önemsiz insanların küçük başarılarını gülünç bir şekilde anlatmaktadır. Buna rağmen kafiyenin düzgün kullanımı şiire ayrıca bir güzellik ve önem katmaktadır. "Mac Flecknoe" adlı eserin, Dryden zamanında başarısız olan bir şaire gönderme olarak yazıldığ1 düşünülmektedir. Dryden'a göre şiirleri başarısız olan bu yazar kendini önemli bir şair olarak görmektedir. Dryden ise bu eseriyle, ilgili yazarı hicivle anlatmıştır. Sonuç olarak Dryden'ın Deneme'de bahsettiği edebi eleştiri kuralların her ne kadar genel olarak edebiyat için geçerliliği olsa da, Dryden'ın kendi doğal yeteneklerine de dayandığını söyleyebiliriz. Dryden'ın oyunlarında kurguladığı zengin hikâye örgüsü ve karakterlerine kattığı duygular onun, edebi dünyada çok iyi bir oyun yazarı olarak tanımlanmasına neden olmuştur. Şairin şiirlerindeki kafiyeler, kullandığı dile hâkim olması ve basit cümle yapılarına ustaca anlam yükleyebilmesi onu öne çıkaran başlıca meziyetlerindendir. 